GRASAS Y ACEITES 65 (2)

April-June 2014, e023

ISSN-L: 0017-3495

doi: http://dx.doi.org/10.3989/gya.122213

\title{
Virgin olive oil color and perceived quality among consumers in emerging olive-growing countries
}

\author{
A. Gámbaro ${ }^{\bowtie}$, L. Raggio, A.C. Ellis and M. Amarillo \\ Universidad de la República, Uruguay \\ School of Chemistry-Food Science and Technology Department-Sensory Evaluation Laboratory \\ Postal address: Gral. Flores 2124, C.P.11800, Montevideo, Uruguay \\ Corresponding author: agambaro@ffq.edu.uy
}

Submitted: 3 December 2013; Accepted: 23 December 2013

SUMMARY: Five virgin olive oil samples were evaluated by 122 consumers for their color acceptability and expected quality on 9-point structured scales. A description of the attributes expected in the different oils was obtained from the responding consumers by means of a check-all-that-apply questionnaire consisting of a list of 17 possible virgin olive oil attributes. Hierarchical cluster analysis led to the identification of two consumer clusters with distinct behavior. Whereas one consumer cluster attributed higher quality to those oils that were greener in color, which they described as tasty, rich-flavored, strong-tasting, herb-flavored and expensive, consumers in the other cluster assumed that greener olive oils were of a poorer quality, as they described them as strange-tasting, strong-tasting, herb-tasting and defective. Despite the contrasting perception of a virgin olive oil's green color, the respondents, irrespective of cluster, presumed that the virgin olive oil that was the yellowest in color was of poor quality and cheap, also assuming that it had a milder taste than the other oils.

KEYWORDS: Color; Consumer; Olive oil; Sensory evaluation

RESUMEN: Influencia del color en la calidad del aceite de oliva virgen percibida por consumidores de un país con olivicultura emergente. 122 consumidores evaluaron el color de 5 muestras de aceite de oliva virgen, midiendo su aceptabilidad y la calidad esperada por medio de una escala estructurada de 9 puntos y describiéndolas por medio de preguntas "marque todo lo que corresponde" que consiste en una lista de 17 términos posibles para atributos de aceites de oliva extra vírgenes. Mediante un análisis de conglomerados jerárquico se identificó a dos grupos de consumidores Los consumidores de ambos grupos consideraron que los aceites más amarillos eran de baja calidad, describiéndolos como baratos y de gusto suave. Un grupo de consumidores asignó puntuaciones de calidad alta a todos los aceites con colores verdes, describiéndolos como sabrosos, aromáticos, con gusto fuerte, con sabor a hierba y caros. El otro grupo de consumidores consideró que los aceites de color verde más intenso eran también de baja calidad, describiéndolos como con sabor extraño, con gusto fuerte, con sabor a hierba y defectuosos. Este estudio demuestra que en los países con olivicultura emergente pero con poca tradición de consumo de aceite de oliva, los consumidores aún no tienen preferencias comerciales claras sobre el color de este producto, aunque coinciden en rechazar y considerar como de baja calidad a los aceites de oliva amarillos posiblemente por asociarlos con los aceites de semillas que habitualmente se encuentran en el mercado.

PALABRAS CLAVE: Aceite de oliva; Color; Consumidores; Evaluación sensorial

Citation/Cómo citar este artículo: Gámbaro A, Raggio L, Ellis AC, Amarillo M. Virgin olive oil color and perceived quality among consumers in emerging olive-growing countries. Grasas Aceites 65 (2): e023. doi: http://dx.doi. org/10.3989/gya.122213.

Copyright: (C) 2014 CSIC. This is an open-access article distributed under the terms of the Creative Commons Attribution-Non Commercial (by-nc) Spain 3.0 Licence. 


\section{INTRODUCTION}

Consumers rely on the intrinsic attributes of food products, especially their sensory attributes, to judge their quality. The study of these attributes enables the design of specific marketing strategies based on consumer expectations and cultural demand.

Olive oil has typically been used in the Mediterranean diet and is culturally rooted in that region (Dekhili et al., 2011). Although it was the subject of controversy at one time (Papaseit, 1986; Gutiérrez González, 1987; Solinas, 1990; COI, 2009), a virgin olive oil's color is not among the classification criteria used to determine its commercial grade. However, consumers perceive a virgin olive oil's color and may reject an oil on account of its color even though the rest of its sensory attributes are deemed suitable (Moyano et al., 2010).

Partition phenomena implicated in the olive oil extraction process determine the distribution of olive pigments between a solid phase (pomace) and two liquid phases (i.e., oil and vegetation water, respectively). In view of the hydrophilic nature of anthocyanides and the lipophilic nature of chloroplast pigments, the former are retained in the pomace and in the vegetation water, whereas the latter (i.e., chlorophylls and carotenoids) are carried into the oil phase (Ranalli et al., 2005). Chlorophylls and carotenoids are responsible for the color of virgin olive oil, which ranges from yellow or golden to deep green (Escolar et al., 2007).

An exploratory study conducted on a sample of olive oil consumers and experts in France and Turkey, showed color to be a major purchase driver among respondents (Dekhili and d'Hauteville, 2006). Further research conducted in the same countries led to the identification of a group of respondents who based their virgin olive oil purchase decision on color and other appearancerelated attributes rather than on factors like price, country of origin, brand, taste or "extra-virgin" status (Dekhili et al., 2011).

Influenced by the dominant olive variety, the commercially preferred color and hue of virgin olive oil vary widely according to region. Whereas the characteristic golden-yellow color of the Arbequina variety is preferred among consumers in Terragona (Spain), virgin olive oils in hues of deep green, characteristic of the Picual variety, are preferred by consumers in Andalucía (Spain). In Umbria (Italy), greenish-yellow hues are the preferred extra virgin olive oil color (Gutiérrez González, 1987; Da Rin, 1991; Tous and Romero, 1992).

Few studies have addressed the relationship between olive oil acceptability and color in nontraditional yet potential virgin olive oil markets. The results of UK surveys showed that olive oil acceptability correlated positively with translucid clarity and negatively with greenish hues in the color of an olive oil (McEwan et al., 1994). These results are consistent with a more recent, US study, according to which consumers disliked the deep green color of one of the tested olive oils (Recchia et al., 2012).

In Uruguay, the local olive oil market $(0.4 \mathrm{~L}$ per capita per annum) is supplied mainly by imports from Spain, Italy and Argentina. However, as of 2002, the local olive-growing sector has expanded rapidly by 500 to 1,000 hectares/year, amounting to a current planted area of 10.000 hectares. As a result, 20 national brands are now available on the local Uruguayan olive oil market, in addition to the traditional imported brands (Uruguay XXI, 2012).

The aim of this study was to examine the influence of the color of virgin olive oil samples on quality perception among consumers in Uruguay, an emerging olive oil-producing country.

\section{MATERIALS AND METHODS}

\subsection{Virgin olive oil samples}

Five virgin olive oils obtained from ripe olive fruits of the 'Itrana', 'Arbequina', 'Coratina', 'Taggiasca' and 'Frantoio' varieties were selected visually exercising care to cover the color range of available virgin olive oils on the Uruguayan market (from pale yellow to deep green). All olive oil samples were extracted using an Abencor laboratory oil mill (Abengoa, Spain).

\subsection{Color characterization}

The color of each olive oil was characterized according to the total pigment content (i.e. chlorophylls and carotenes). Chlorophyll determinations were made by means of absorbance measurements at $670 \mathrm{~nm}$ (corresponding to the maximum absorbance of phaeophytin), while $470 \mathrm{~nm}$ (corresponding to the maximum absorbance of luthein) was used for the determinations of carotenes (Minguez-Mosquera et al., 1991; Balzarini et al., 2008). The total pigment concentration in each oil was expressed as the sum of its chlorophyll content and its carotene content. All measurements were made in triplicate.

The tested oils were placed in 50-mL transparent glass bottles coded with one letter and a two-digit random number (Figure 1).

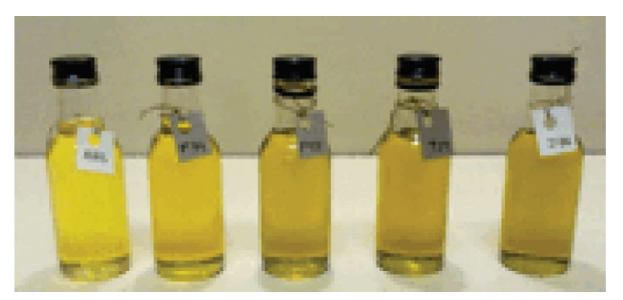

FIgURE 1. Presentation of virgin olive oil samples. 


\subsection{Consumer study}

The consumer study was conducted in the city of Montevideo (Uruguay) using 122 habitual and occasional virgin olive oil consumers recruited randomly in shopping malls, food courts and other public places, including university facilities. Respondents answered a brief questionnaire of socio-demographic variables (age, gender, civil status, number of persons in the household, number of children in the household and educational level) and were asked to rate their virgin olive oil consumption frequency (Table 1).

Although the non-probabilistic sampling methodology and the recruitment procedure did not provide a statically representative sample of Uruguayan consumers, the sample included a wide range of socio-demographic backgrounds. The sample was found to be biased toward a high educational background, a fact which may be ascribed to a generally greater willingness of these individuals to participate in surveys.

Having completed the questionnaire, respondents were asked to conduct the sensory evaluation at a convenient date, with the incentive that they would participate in a raffle with a basket of goods as the prize. The evaluation was conducted in the tasting room of the Sensory Evaluation Laboratory of the School of Chemistry of Uruguay's Universidad de la República, designed in conformity with ISO 8589 standards (ISO, 1988).

The oil samples were presented monadically in random order. Consumers were asked to evaluate the acceptability of the color of samples on a 9-point structured hedonic scale ranging from utter dislike (1) through to extreme liking (9), using a white background and natural lighting. Respondents rated the expected quality of the oils on a 9-point structured scale ranging from very poor (1) through to very good (9). Finally, to elicit the respondents' descriptions of their expectations of each of the oils, they were provided with a checkall-that-apply questionnaire consisting of the following list of 17 possible olive oil attributes: tasty, rich-flavored, bitter, spicy, fruity, strong-flavored, mild-flavored, herb-flavored, delicious, sweet, freshflavored, disgusting, disagreeable, strange-tasting, defective, expensive and cheap.

\subsection{Statistical analysis}

Analysis of variance (ANOVA) was carried out on pigment content and on acceptability and quality perception scores, using "sample" as a variation factor. Significant differences between mean values were determined using the Tukey test $(p<0.05)$.

Quality perception data were also subjected to hierarchical cluster analysis, in order to identify consumer clusters with different perceptions of the olive oil samples. The formation of clusters was based on Ward's aggregation criterion and the calculation of Euclidean distances between data points. The chisquare test was performed to determine significant differences $(p<0.05)$ in the frequency distribution of socio-demographic variables and in consumption frequency between the clusters.

Afterwards, an ANOVA was performed on acceptability and quality perception data, using "sample", "cluster" and interaction between the two as sources of variation. Significant differences between mean values were determined using the Tukey test $(\mathrm{p}<0.05)$.

For the "check-all-that-apply" questions, the frequency of mention of each attribute was counted for each sample. Cochran's Q test was performed for each attribute to assess differences in consumer perception for each oil sample.

Finally, the relationship between the samples and the attributes used by each consumer cluster was

TABLE 1. Socio-demographic data and virgin olive oil consumption frequency among respondents $(\mathrm{n}=122)$

\begin{tabular}{llr}
\hline \multirow{2}{*}{ Gender } & Male & $49(40.2 \%)$ \\
Age & Female & $73(59.8 \%)$ \\
& $18-29$ yrs. & $52(42.6 \%)$ \\
& $30-45$ yrs. & $30(24.6 \%)$ \\
Education level & Over 45 yrs. & $40(32.8 \%)$ \\
& Secondary education completed & $31(25.4 \%)$ \\
& Tertiary education unfinished & $62(50.8 \%)$ \\
Civil status & University professionals & $21(23.8 \%)$ \\
& Lives in partnership & $61(50.0 \%)$ \\
Persons in the household & Lives alone & $61(50.0 \%)$ \\
Children in the household & $1-2$ & $64(52.5 \%)$ \\
& 3 or more & $58(47.5 \%)$ \\
Olive oil consumption frequency & 0 & $107(83.6 \%)$ \\
& 1 or more & $20(16.4 \%)$ \\
\hline
\end{tabular}


TABLE 2. Pigment content and rated color acceptability and perceived quality according to virgin olive oil sample

\begin{tabular}{llccccc}
\hline Sample & Color description & $\begin{array}{c}\text { Carotenes } \\
\mathbf{m g} \cdot \mathbf{k g}^{-1} \text { oil }\end{array}$ & $\begin{array}{c}\text { Chlorophylls } \\
\mathbf{m g} \cdot \mathbf{k g}^{-1} \text { oil }\end{array}$ & $\begin{array}{c}\text { Total pigments } \\
\mathbf{m g} \cdot \mathbf{k g}^{-1} \text { oil }\end{array}$ & $\begin{array}{c}\text { Acceptability } \\
\text { (9-point scale) }\end{array}$ & $\begin{array}{c}\text { Quality } \\
\text { (9-point scale) }\end{array}$ \\
\hline I & Pale yellow & $2.6 \mathrm{a}$ & $3.2 \mathrm{a}$ & $5.7 \mathrm{a}$ & $4.0 \mathrm{a}$ & $4.4 \mathrm{a}$ \\
II & Golden yellow & $3.9 \mathrm{~b}$ & $6.0 \mathrm{~b}$ & $9.9 \mathrm{~b}$ & $5.5 \mathrm{~b}$ & $5.6 \mathrm{~b}$ \\
III & Light green & $5.2 \mathrm{c}$ & $10.9 \mathrm{c}$ & $16.1 \mathrm{c}$ & $6.7 \mathrm{c}$ & $6.8 \mathrm{c}$ \\
IV & Green & $6.9 \mathrm{~d}$ & $12.7 \mathrm{~d}$ & $19.6 \mathrm{~d}$ & $6.5 \mathrm{c}$ & $6.7 \mathrm{c}$ \\
V & Deep green & $8.1 \mathrm{e}$ & $14.0 \mathrm{e}$ & $22.1 \mathrm{e}$ & $6.3 \mathrm{c}$ & $6.2 \mathrm{c}$ \\
\hline
\end{tabular}

Different letters in one column indicate significant differences according to the Tukey test $(\mathrm{p}<0.05)$.

assessed by means of Multiple Factorial Analysis (Bécue-Bertaut and Pagès, 2008).

All statistical analyses were carried out with XL-Stat 2012 software (Addinsoft, NY) and R language (R Development Core Team, 2007).

\section{RESULTS AND DISCUSSION}

\subsection{Pigment content}

The pigment contents of the different virgin olive oil samples are shown in Table 2. All samples had significantly different chlorophyll, carotene and total pigment contents $(\mathrm{p}<0.05)$, confirming that the selection of oil samples conducted visually was satisfactory for the study. The color of the olive oils in this study is described in Table 2.

\subsection{Consumer study}

Color acceptability and expected quality ratings provided by respondents differed significantly $(p<0.05)$ among the evaluated oils. In addition, acceptability and quality ratings were found to have a highly significant correlation $(\mathrm{p}<0.0001)$, suggesting that in the absence of other sensory data, consumers did not distinguish between their appreciation of color and their opinion of the oil samples' quality.

Significantly lower ratings were assigned to the olive oil of the lightest yellow color (oil sample I) than to the rest of the studied oils (Table 2). Although higher than for pale yellow oil (I), both acceptability and quality ratings for golden yellow oil (II) were also lower than for the other oils. Based on a minimum score of six out of nine as an indicator of a product's commercialization potential (Muñoz et al., 1992), the respondents appear to have disliked those oils that were yellow in color, while they seem to have liked more, and expected a higher quality of those which were green. Because the olive-growing sector is only just emerging in Uruguay, these consumers may be unacquainted with the color of virgin olive oils extracted from locally grown olive varieties, unlike the case in other, more traditional olive oil consuming regions, and thus tend to associate a yellow-colored oil with seed oils available on the local market.

The remaining oil samples (III, IV and V), which were greener in color, were rated higher than the commercial limit, with no significant differences among their respective ratings.

Hierarchical cluster analysis conducted on expected quality data led to the identification of two consumer clusters amounting to $62.3 \%(\mathrm{n}=76)$ and $37.7 \%(n=46)$, respectively, of the consumer sample, as shown in Table 3. Because color acceptability data followed the same trend as for expected quality, only the latter are shown.

None of the socio-demographic variables considered in this study, nor consumption frequency, was found to differ significantly $(p>0.05)$ between the two clusters. This clearly suggests that other, unaccounted factors may influence an individual's perception of virgin olive oil quality and its acceptability. Such unaccounted factors may relate to subjective knowledge of virgin olive oil facts among the surveyed population (Gámbaro et al., 2013).

Previous studies have demonstrated that Uruguayan consumers perceive virgin olive oil differently from the rest of locally available edible oils, regarding it as a costly, high-quality gourmet oil (Gámbaro et al., 2011). The fact that these consumers might associate a yellow-colored oil with lower quality, locally available seed oils like corn, sunflower, soybean and rice oils suggests that they may have a preference for those

TABle 3. Perceived quality (9-point scale)

\begin{tabular}{lcc}
\hline Sample & Cluster $\mathbf{1}(\mathbf{n}=\mathbf{7 6})$ & Cluster $\mathbf{2}(\mathbf{n}=\mathbf{4 6})$ \\
\hline I & $4.2^{\mathrm{aA}}$ & $4.8^{\mathrm{aA}}$ \\
II & $5.8^{\mathrm{bA}}$ & $5.3^{\mathrm{aA}}$ \\
III & $7.1^{\mathrm{cA}}$ & $6.1^{\mathrm{bB}}$ \\
IV & $7.8^{\mathrm{dA}}$ & $4.9^{\mathrm{aB}}$ \\
V & $7.1^{\mathrm{cA}}$ & $4.8^{\mathrm{aB}}$ \\
\hline
\end{tabular}

Different lower case letters in one column indicate significant differences among samples within one cluster, according to the Tukey test $(\mathrm{p} \leq 0.05)$.

Different upper case letters in one row indicate significant differences between clusters for one olive oil sample, according to the Tukey test $(\mathrm{p}<0.05)$. 
virgin olive oils of a distinct greenish color, clearly different from that of seed oils. In addition to the above, it is worth noting that, unlike the case of Mediterranean countries, where color preferences seem to be influenced by the locally grown olive variety, in countries where olive-growing is an emerging activity, as is the case in Uruguay, there is as yet no traditionally grown or characteristic olive variety of the local sector that consumers could resort to as a reference.

\subsection{Check-all-that-apply questionnaire}

Tables 4 and 5 show the frequency of mention of each of the words in the check-all-that-apply questionnaire according to the consumer cluster. Tasty, mild-tasting, strong-tasting, fresh-flavored, rich-flavored, expensive and cheap were the most frequently used words regardless of the cluster. The frequencies of mention of those words with a negative connotation like disgusting, disagreeable and defective did not differ significantly between the clusters ( $p>0.05$ ). Moreover, the low frequencies of mention of such negative attributes suggest that, overall, the consumers did not base their expected quality ratings on tasterelated attributes but on the color of the different oils.

Both consumer groups described yellow oils (oil samples I and II) as mild-tasting and cheap, reaffirming the above suggestion that Uruguayan consumers might associate yellow-colored edible oils with seed oils.
Cluster 1 found the green oils (oil samples III, IV and V) tasty, rich-flavored, strong-tasting, herbflavored and expensive. The green and the deep green oil (IV and V) had higher numbers of mention of the attributes tasty, strong-tasting and expensive than the light green oil (III), while the latter had a higher number of mentions of the attribute rich-flavored. The green oil (IV) also had the highest number of mentions of the attributes herb-flavored and delicious.

Cluster 2 consumers also associated a strong taste and an herbal flavor with green virgin olive oils. However, unlike the case with cluster 1 consumers, lower frequencies of mention of tasty, richflavored, fresh-flavored and expensive attributes were provided by cluster 2 consumers for those oils which were greener in color (IV and V).

The above observation may explain the different acceptability and preference patterns of the two consumer groups. Cluster 1 consumers possibly prefer strong-tasting virgin olive oils and presumably through an association between an olive oil's green color and its taste intensity, preferred the green oils and thought that they were expensive, rating them as high quality.

In contrast, cluster 2 consumers possibly dislike strong-tasting virgin olive oils and may have rejected the green and the deep green oil (IV and V) in terms of color acceptability and expected quality presumably through the same association between color, taste intensity and herbal flavor.

TABLE 4. Frequency of mention of attributes comprising the check-all-that-apply questionnaire: Cluster $1(\mathrm{n}=76)$

\begin{tabular}{|c|c|c|c|c|c|}
\hline \multirow[b]{2}{*}{ Attributes } & \multicolumn{5}{|c|}{ Virgin olive oil sample } \\
\hline & $\mathbf{I}$ & II & III & IV & $\mathbf{V}$ \\
\hline Tasty*** & 10.5 & 34.2 & 53.9 & 61.8 & 63.2 \\
\hline Rich-flavored ${ }^{* * *}$ & 15.8 & 30.3 & 61.8 & 57.9 & 51.3 \\
\hline Bitter $^{\text {ns }}$ & 5.3 & 9.2 & 18.4 & 15.8 & 15.8 \\
\hline Spicy*** & 0.0 & 9.2 & 18.4 & 17.1 & 18.4 \\
\hline Fruity $^{\text {ns }}$ & 6.6 & 10.5 & 9.2 & 7.9 & 10.5 \\
\hline Strong-tasting*** & 2.6 & 7.9 & 38.2 & 44.7 & 46.1 \\
\hline Mild-tasting $* * *$ & 59.2 & 48.7 & 15.8 & 15.8 & 18.4 \\
\hline Herb-flavored $* * *$ & 1.3 & 13.2 & 18.4 & 28.9 & 22.4 \\
\hline Delicious $* * *$ & 2.6 & 5.3 & 10.5 & 25.0 & 14.5 \\
\hline Sweet ${ }^{\mathrm{ns}}$ & 9.2 & 5.3 & 1.3 & 0.0 & 1.3 \\
\hline Fresh-flavored* & 17.1 & 27.6 & 31.6 & 38.2 & 27.6 \\
\hline Disgusting $^{\text {ns }}$ & 3.9 & 0.0 & 0.0 & 0.0 & 0.0 \\
\hline Disagreeable $^{\text {ns }}$ & 5.3 & 3.9 & 2.6 & 0.0 & 1.3 \\
\hline Strange-tasting** & 18.4 & 10.5 & 6.6 & 2.6 & 5.3 \\
\hline Defective $^{\text {ns }}$ & 0.0 & 7.9 & 5.3 & 1.3 & 0.0 \\
\hline Expensive ${ }^{* * *}$ & 3.9 & 13.2 & 26.3 & 50.0 & 43.4 \\
\hline Cheap*** & 59.2 & 27.6 & 3.9 & 2.6 & 6.6 \\
\hline
\end{tabular}

$* \mathrm{p}<0.05 ; * * \mathrm{p}<0.01 ; * * * \mathrm{p}<0.001 ;$ ns non-significant difference $(\mathrm{p}>0.05)$ according to Cochran's $\mathrm{Q}$ test. 
TABLE 5. Frequency of mention of attributes comprising the check-all-that-apply questionnaire: Cluster $2(\mathrm{n}=46)$

\begin{tabular}{|c|c|c|c|c|c|}
\hline \multirow[b]{2}{*}{ Attributes } & \multicolumn{5}{|c|}{ Virgin olive oil sample } \\
\hline & I & II & III & IV & $\mathbf{V}$ \\
\hline Tasty** & 13.0 & 30.4 & 45.7 & 21.7 & 23.9 \\
\hline Rich-flavored*** & 13.0 & 45.7 & 47.8 & 26.1 & 23.9 \\
\hline Bitter $^{\text {ns }}$ & 10.9 & 17.4 & 23.9 & 23.9 & 21.7 \\
\hline Spicy** & 0.0 & 2.2 & 10.9 & 15.2 & 10.9 \\
\hline Fruity $^{\text {ns }}$ & 2.2 & 15.2 & 8.7 & 4.3 & 6.5 \\
\hline Strong-tasting $* * *$ & 6.5 & 13.0 & 21.7 & 32.6 & 69.6 \\
\hline Light-tasting $* * *$ & 50.0 & 37.0 & 28.3 & 13.0 & 6.5 \\
\hline Herb-flavored ${ }^{* * *}$ & 2.2 & 15.2 & 21.7 & 34.8 & 32.6 \\
\hline Delicious** & 0.0 & 6.5 & 19.6 & 8.7 & 2.2 \\
\hline Sweet* & 15.2 & 8.7 & 2.2 & 2.2 & 2.2 \\
\hline Fresh-flavored $^{\text {ns }}$ & 23.9 & 19.6 & 32.6 & 19.6 & 13.0 \\
\hline Disgusting $^{\text {ns }}$ & 6.5 & 4.3 & 2.2 & 4.3 & 4.3 \\
\hline Disagreeable $^{\text {ns }}$ & 13.0 & 2.2 & 2.2 & 10.9 & 15.2 \\
\hline Strange-tasting** & 13.0 & 8.7 & 4.3 & 15.2 & 28.3 \\
\hline Defective $^{\text {ns }}$ & 0.0 & 12.2 & 2.2 & 13.0 & 10.9 \\
\hline Expensive* & 8.7 & 19.6 & 32.6 & 21.7 & 21.7 \\
\hline Cheap*** & 63.0 & 23.9 & 6.5 & 17.4 & 10.9 \\
\hline
\end{tabular}

${ }^{*} \mathrm{p}<0.05 ; * * \mathrm{p}<0.01 ;{ }^{* * *} \mathrm{p}<0.001 ;$ ns non-significant difference $(\mathrm{p}>0.05)$ according to Cochran's $\mathrm{Q}$ test.

A multiple Factor Analysis was conducted considering the number of words assigned by each consumer cluster to the tested oils. Figure 2 shows that the different oil samples were clearly distinguished by consumers. Figure 3 shows a strong correlation among some of the check-all-that-apply items, suggesting that consumers associated these attributes with one another. Such was the case with cheap,

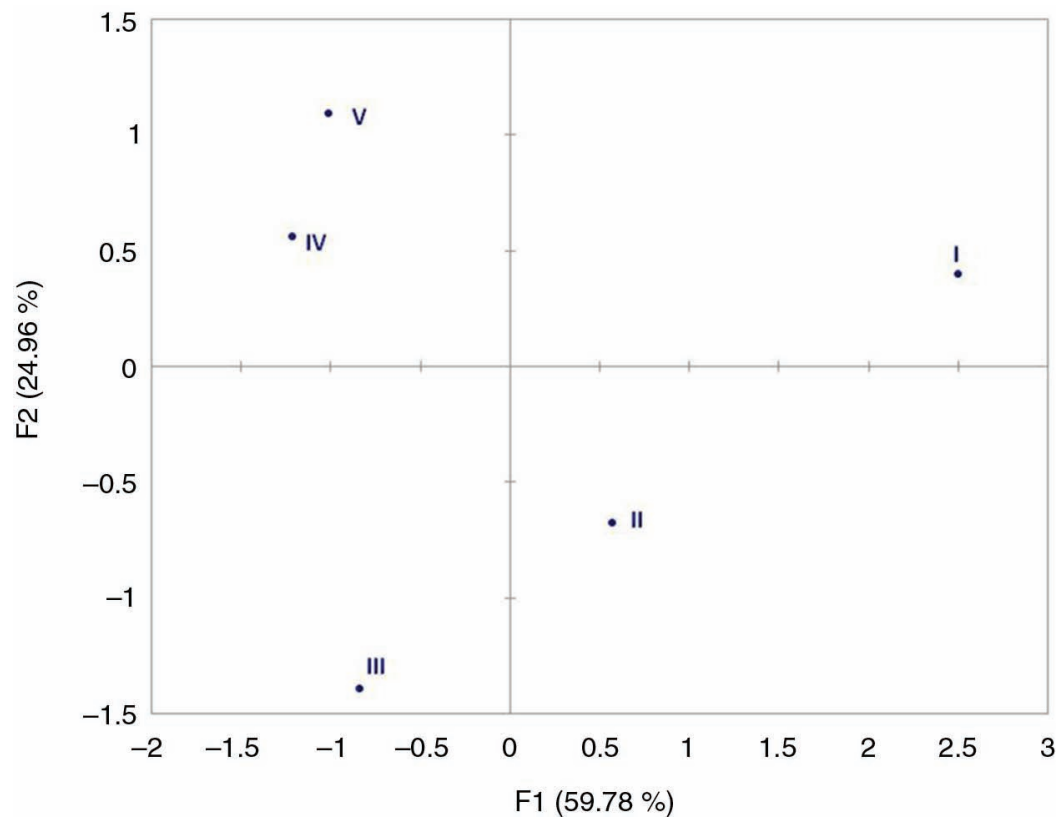

FIGURE 2. Results of multiple factor analysis (representation of virgin olive oil samples). 


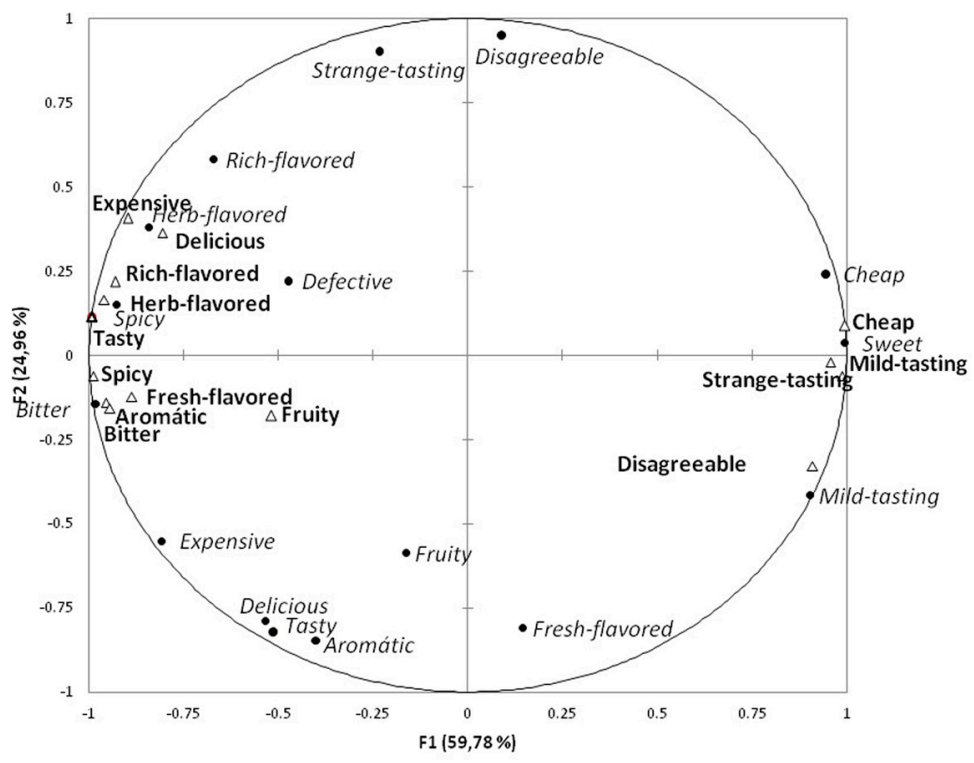

FIGURE 3. Results of multiple factor analysis (cluster 1 data shown as unfilled triangles labeled in bold type; cluster 2 data shown as filled dots labeled in italics).

mild-tasting, bitter, spicy, herb-flavored and strongtasting, all of which had a similar frequency of mention for each oil sample.

Cluster 2 consumers (shown in italics) associated the light green oil (sample III) with the attributes expensive, delicious, tasty, rich-flavored and fruity, whereas both the green and the deep green oil (samples IV and V) were described by these consumers as strange-tasting, strong-tasting, herb-flavored and defective. Presumably, consumers in this cluster found the strong taste and herbal flavor of virgin olive oil disagreeable and thus tended to associate these attributes with the presence of defects and a strange taste.

In contrast, oil that was green or deep green (IV and V) was presumed expensive and delicious by cluster 1 consumers, consistent with the color acceptability and expected quality ratings provided by these consumers.

Regardless of cluster, the respondents associated the oil closest to yellow in color (oil sample I) with the attributes cheap and mild-tasting.

\section{CONCLUSIONS}

The results of this study show that consumers in non-traditional, emerging olive-growing countries appear to not yet have a clear preference regarding a virgin olive oil's color. Nevertheless, a clear tendency was found among the respondents to reject those oils of a yellow color (pale yellow and golden yellow), assuming that it was indicative of poorquality olive oils, presumably because of an association with yellow-colored seed oils widely available on the local Uruguayan market.

\section{REFERENCES}

Balzarini MG, Gonzalez L, Tablada M, Casanoves F, Di Rienzo JA, Robledo CW. 2008. Manual del Usuario. Editorial Brujas, Córdoba, Argentina.

Bècue-Bertaut M, Pagès J. 2008. Multiple factor analysis and clustering of a mixture of quantitative, categorical and frequency data. Comput. Stat. Data Anal. 52, 3255-3268. http://dx.doi.org/10.1016/j.csda.2007.09.023.

COI 2009. Norma comercial aplicable a los aceites de oliva y los aceites de orujo de oliva. Consejo Oleícola Internacional, $\mathrm{COI} / \mathrm{T} .15 / \mathrm{NC} \mathrm{n}^{\circ} 3 / \mathrm{Rev} .4$.

Da Rin L. 1991. La nuova olivicultura umbra. L'lnformatore Agrario 10, 213-214.

Dekhili S, d'Hauteville F. 2006. Les dimensions perçues de l'image de la región d'origine. Cas de l'huile d'olive. 22ème Congrès de l'Association Française de Marketing (AFM) (p. 19), France: Nantes, 11-12 Mai.

Dekhili S, Sirieix L, Cohen E. 2011. How consumers choose olive oil: The importance of origin cues. Food Qual. Prefer. 22, 757-762. http://dx.doi.org/10.1016/j.foodqual. 2011.06.005.

Escolar D, Haro MR, Ayuso J. 2007. The color space of foods: Virgin olive oil. J. Agr. Food Chem. 55, 2085-2093. http:// dx.doi.org/10.1021/jf062899v.

Gámbaro A, Dauber C, Ares G, Ellis AC. 2011. Studying uruguayan consumers' perception of vegetables oils using Word Association. Brazilian J. Food Tech. Special Issue 2011, 131139. DOI: 10.4260/BJFT201114E000116.

Gámbaro A, Ellis AC, Prieto V. 2013. Influence of Subjective Knowledge, Objective Knowledge and Health Consciousness on Olive Oil Consumption-A Case Study. Food Nutr. Sci. 4, 445-453. http://dx.doi.org/10.4236/fns.2013.44057.

Gutiérrez González R. 1987. Parámetros de calidad en el aceite de oliva. I. En su utilización en crudo. Pon. $2^{a}$. III Simp. Nal. Aceite de Oliva. Jaén.

ISO 1988. Sensory Analysis: General Guidance for the Design of Test Rooms, ISO 8589. International Organization for Standardization, Geneve, Switzerland.

McEwan JA. 1994. Consumer attitudes and olive oil acceptance: the potential consumer. Grasas Aceites 45, 9-15. http:// dx.doi.org/10.3989/gya.1994.v45.i1-2.963.

Minguez-Mosquera MI, Rejano-Navarro L, Gandul-Rojas B, Sánchez-Gómez AH, Garrido-Fenández J. 1991. 
Color-Pigment Correlation in Virgin Olive Oil. J. Am. Oil Chem. Soc. 68, 332-336. http://dx.doi.org/10.1007/ BF02657688.

Moyano MJ, Heredia FJ, Meléndez-Martínez AJ. 2010. The Color of Olive Oils: The Pigments and Their Likely Health Benefits and Visual and Instrumental Methods of Analysis. Compr. Rev. Food Sci. Food Saf. 9, 278-291. http://dx.doi. org/10.1111/j.1541-4337.2010.00109.x.

Muñoz AM, Civille VG, Carr BT. 1992. Sensory evaluation in quality control. Van Mostrand Reinhold. USA.

Papaseit J. 1986. El color del aceite de oliva extra virgen, característica de calidad. Grasas Aceites. 37, 204-206.

Ranalli A, Malfatti A, Lucera L, Contento S, Sotiriuo E. 2005. Effects of the processing techniques on the natural colourings and the other functional constituents in virgin olive oil. Food Res. Int. 38, 873-878. http://dx.doi.org/10.1016/j. foodres.2005.02.011.

Recchia A, Monteleone E, Tuorila H. 2012. Responses to extra virgin olive oils in consumers with varying commitment to oils. Food Qual. Prefer. 24, 153-161. http://dx.doi. org/10.1016/j.foodqual.2011.10.009.

Solinas M. 1990. Caratteristiche analitiche degli oli vergini di oliva e marchio di qualilá. L'Informatore Agrario 47, 19-25.

Tous Martí J, Romero Aroca A. 1992. Caracterización del color de los aceites de oliva vírgenes de cultivares catalanes. Grasas Aceites 43, 347-351. http://dx.doi.org/10.3989/ gya.1992.v43.i6.1131.

Uruguay XXI. 2012. Sector Olivícola en Uruguay. URUGUAY XXI. Promoción de Inversiones y exportaciones. Presidencia de la República Oriental del Uruguay. p.5. 